\title{
Characteristics of Palangkaraya fibrous peat
}

\author{
Faisal Estu Yulianto ${ }^{1, *}$, Fuad Harwadi ${ }^{2}$, and Rusdiansyahi ${ }^{3}$ \\ ${ }^{1}$ Departement of Civil Engineering, Universitas Madura, Jawa Timur, Indonesia \\ ${ }^{2}$ Departement of Civil Engineering, Universitas Kaltara, Kalimantan Utara, Indonesia \\ ${ }^{3}$ Departement of Civil Engineering, Universitas Lambung Mangkurat, Kalimantan Selatan, Indonesia
}

\begin{abstract}
Palangkaraya fibrous peat soil is a soil with high organic content and was formed due to decomposition of plants in submerged areas for long periods. In the tropics, peat has a high fiber content that affects the physical and engineering characteristic and have different behavior with clay. Laboratory and field tests were conducted to determine the physical and engineering characteristic of fibrous peat and to compare it with clay. The results of the tests on fibrous peat show peat soil parameter very different from clays. The unit weight of peat is $1.04 \mathrm{gr} / \mathrm{cm}^{3}$ with specific gravity is 1.4 and water content reach $650 \%$. This physical parameter shows that peat is a very soft soil that is dominated by water in its structure. Organic content of peat reached $97 \%$ with a very low ash content of $3 \%$. This behavior indicates that the decomposition of plants causes physical properties of peat that are very different from clays. The bearing capacity of the peat is also very low. The shear strength was about 26.8 $\mathrm{kPa}(\sigma \mathrm{v}=50 \mathrm{kPa})$ and was dependent on the fiber distribution in the sample under test. Vane shear test results also show the same thing that is 5-7 $\mathrm{kPa}$. The very different behavior of fibrous peat with clay is the consolidation. Peat has 4 stages of compression wherein secondary compression is the main compression. This behavior is due to the fibrous peat has two pores, that are micropores and macropores. The results of comparisons can serve as a basis for determining appropriate peat soil improvement methods.
\end{abstract}

\section{Introduction}

Fibrous peat Palangkaraya is classified as tropical peat soils. Its formed by the decomposition process of marsh plants such as a variety of grass, mangrove, pandanus, ferns, areca, and other marsh plants over than 5000 years [1]. Because the area of marsh plant is always humid and stagnate by water and oxygen circulation is not good, so that the process of humification by bacteria does not occur correctly. As a result, the fibers of the marsh plant are still visible and acutely affect the behavior of the peat soil very much.

MacFarlane and Radforth [2] stated that peat soils are divided into 2 (two) types base on their fiber content, there is fiber content $\geq 20 \%$, it called fibrous Peat, while peat soil with $<$ $20 \%$ fiber content is amorphous granular peat. Fibrous peat and amorphous granular peat soils can be classified as very soft soils and generally have a low bearing capacity and high

*Corresponding author: faisal_ey@yahoo.co.id 
settlement. If the amorphous granular peat soil has a behavior similar with clay, the fibrous peat soil has very different behavior from clay due to its fiber distribution so that the classical theory of clay cannot be applied to fibrous peat soil to determine its physical and engineering parameters. Based on the explanation above, this paper written to explain the differences of characteristics based on the results of field and laboratory testing so that we can determine correct method of soil improvement if the civil construction on the fibrous peat soil.

\section{Peat soil studied}

Fibrous peat soil samples were taken at Bereng Bengkel, Palangkaraya, Central Kalimantan. Peat soil samples were taken in undisturbed condition by using PVC tubes (20 $\mathrm{cm}$ high) of 20 tubes. The undisturbed peat soil sampling process is shown in Fig. 1.

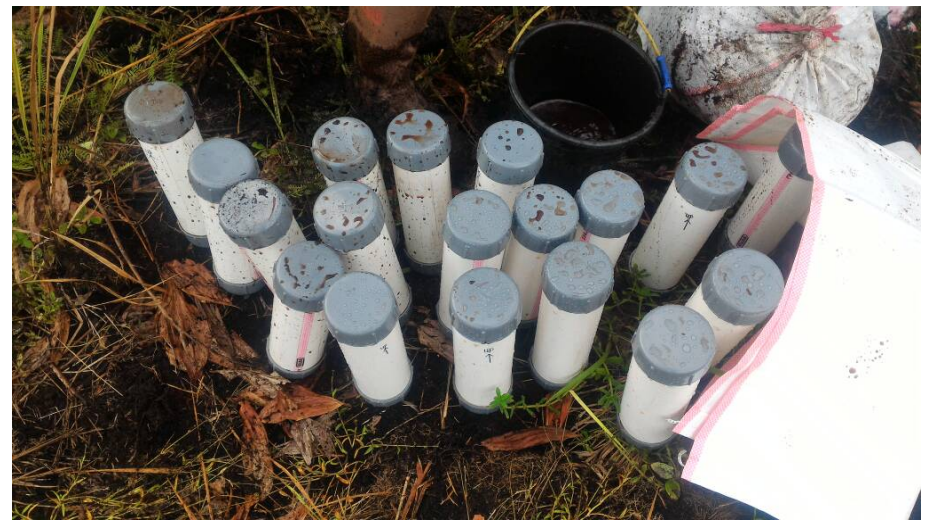

Fig. 1. Samples of undisturbed peat soil.

Field and laboratory tests were conducted to determine and identify the behavior of the Palangkaraya fibrous soil. Field testing that can be done is a unit weight test with sand cone method, acidity test with $\mathrm{pH}$ meter and peat shear strength through Vane Shear (Fig. 2).

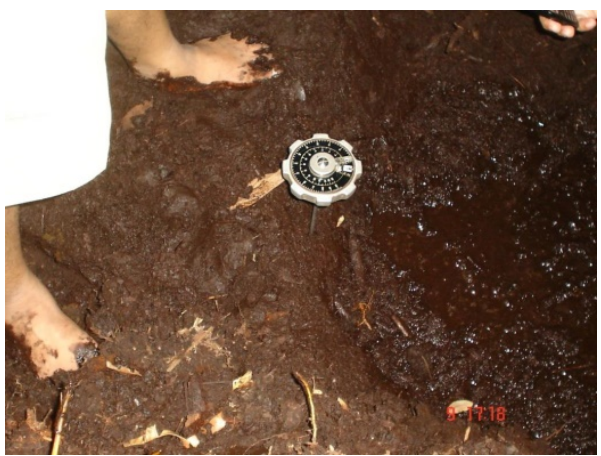

(a)

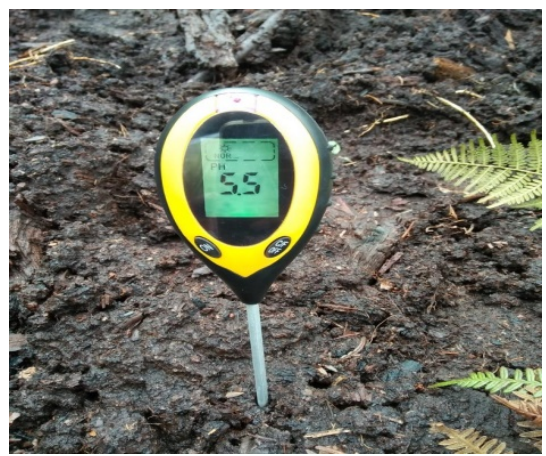

(b)

Fig. 2. Field testing; (a) Vane Shear test, (b) Acidity test.

While laboratory testing covers the physical and engineering properties of fibrous peat. Tests of physical properties include unit weight, fiber content, specific gravity test, water content, organic content, ash content, and fiber distribution. While engineering properties test of the fibrous peat covers the consolidation test and direct shear. All tests performed are based on Peat Testing Manual [3]. 


\subsection{Physical properties of Palangkaraya fibrous peat}

The properties of the Palangkaraya fibrous peat soil resulted from laboratory/field testing is shown by Table 1 . The results of the test show that the Palangkaraya fiber peat soil is still in the intervals of other researcher [4-12]. ASTM D4427-84 states that peat soil classification is based on fiber content, ash content, acidity, and water content. Table 1 shows that Palangkaraya peat soil has the fiber content of $59.6 \%$, ash content of $2 \%$, and acidity $<5$ and it is classified as Hemic fibrous peat soil with low ash content and high acidity.

Table 1. Palangkaraya fibrous peat soil parameters.

\begin{tabular}{|c|c|c|c|}
\hline Soil parameters & Unit & Values & $\begin{array}{c}\text { Previous } \\
\text { studies [4-12] }\end{array}$ \\
\hline Specific Gravity (Gs) & - & 1.37 & $1.4-1.7$ \\
\hline Water content $\left(\mathrm{w}_{\mathrm{c}}\right)$ & $\%$ & 670.00 & $450-1500$ \\
\hline Unit weight $(\gamma t)$ & $\mathrm{gr} / \mathrm{cm}^{3}$ & 0.99 & $0.9-1.25$ \\
\hline Dry Unit weight $(\gamma d)$ & $\mathrm{gr} / \mathrm{cm}^{3}$ & 0.14 & - \\
\hline Void ratio (e ) & - & 11.40 & 6.89-11.09 \\
\hline Acidity $(\mathrm{pH})$ & - & $3.5-5.0$ & $3-7$ \\
\hline Organic content $(\mathrm{Oc})$ & $\%$ & 98.00 & $62.5-98$ \\
\hline Ash content (Ac) & $\%$ & 2.00 & $2-37.5$ \\
\hline Fiber content $(\mathrm{Fc})$ & $\%$ & 59.60 & $39.5-61.3$ \\
\hline Coarse fiber content & $\%$ & 56.25 & $35.35-49.69$ \\
\hline Medium fiber content & $\%$ & 29.38 & $31.94-35.84$ \\
\hline Fine fiber content & $\%$ & 14.37 & $18.37-29.00$ \\
\hline Direct shear: Phi $(\varnothing)$ & 0 & $25,36,42$ & $30^{\circ}-50^{\circ}$ \\
\hline Cohesion: $\mathrm{C}$ & $\mathrm{kPa}$ & 0.50 & - \\
\hline Vane shear & $\mathrm{kPa}$ & $5,7,12$ & $5-10$ \\
\hline
\end{tabular}

The specific gravity (Gs) of Palangkaraya's fibrous peat soil is 1.37 . It is very different from clay and even organic clay [13]. This value indicates that the peat soil has a high organic content (98\%) according to MacFarlane's [14] statement that the Gs of peat still in the range of 1.4-1.7. It will increase to 2 if contaminated by minerals. The high organic content of Palangkaraya fibrous peat soil have consequences to the acidity of the peat $(<5)$ so it unsafe for building materials.

The unit weight $(\gamma t)$ and dry unit weight $(\gamma d)$ of Palangkaraya fibrous peat are 0.99 $\mathrm{gr} / \mathrm{cm}^{3}$ and, $0.14 \mathrm{gr} / \mathrm{cm}^{3}$ while high water content $670 \%$. It shows that the most extensive material in peat soil is water about six times the solid. It means that peat soil is soil with the large void ratio (11.44). The fiber content of peat studied reached $59.6 \%$ with a coarse fiber 
dominance of $56.25 \%$ [2]. This indicates that the decomposition process is still slow so that the coarse and medium fibers are still clearly visible and the peat studied is included in H4 based on the Von Post classification [15]. Physical parameters of Palangkaraya fibrous soil given in Table 1 shows very different values with clay so that the fibrous peat physical behavior will affect the engineering behavior. In another hand, the condition of peat pore is also very different from clay soil if the clay has one pore then the fibrous peat has two pores, ie macropore is the pore among the peat fibers and micropore is a pore in the peat fiber as shown by image of Scanning Electron Microscope/SEM (Fig. 3).

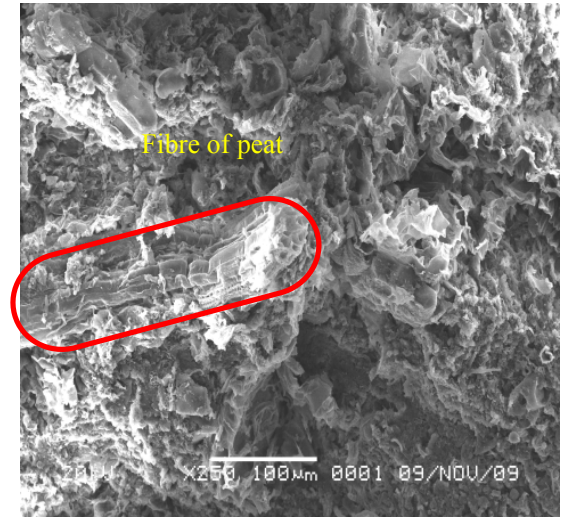

(a)

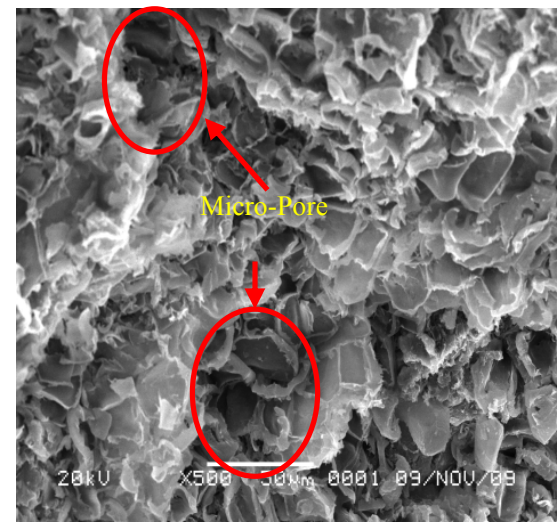

(b)

Fig. 3. Image of SEM of fibrous peat soil: (a) 1000 magnification, (b) 2000 magnification [9].

\subsection{Engineering properties of Palangkaraya fibrous peat}

Peat soil is frictional material or noncohesive material [16] so the shear strength only relies on the strength of the shear angle $(\phi)$. Therefore, the fiber distribution on peat soils very affects the value of the shear angle. From 3 (three) times direct shear testing conducted got a different value of shear angle that is $25^{\circ}, 36^{\circ}$ dan $42^{\circ}$; This behavior is due to the presence of different fiber sizes on each sample of the peat tested. However, the results obtained are still in accordance with the Landva statement [17] wherein the shear angle value $(\phi)$ of fibrous peat soils is in the range $27^{\circ}-32^{\circ}$.

Peat soils have the character that easily compresses when there is a load on it (High Compressibility); This is because peat soils have a large pore. The amorphous granular peat has a compression behavior similar to the clay; However, the compressible behavior of fibrous peat is very different from clay soil. This is indicated by the compression curve (e vs $\log \mathrm{t}$ ) of the fibrous peat soil (Fig. 4). The result of the laboratory test done by Terzaghi method [18]. The compression curve has two broken lines so that the compression index needed to predict compression cannot be obtained when using the Terzaghi method. Mochtar [5] introduced a one-step loading method to determine compression in fibrous peat.

Yulianto and Mochtar [10] explained that the consolidation curve of fibrous peat soils consists of 4 components, namely immediate compression (si), primary compression (sp), secondary compression (ss) and tertiary compression (st) as shown in Fig. 5. Primary compression is the process of water discharge from macropore that occurred in a short time. While secondary compression occurs for a long time and it is the process of water discharge from micropore to macropore, and tertiary compression is the compression caused by the decomposition of fibers peat. 
Based on those, Gibson and Lo [19] Dhowian and Edil [20] provide a method to determine the compression of fibrous peat soil with one step loading until 14 days. Amount of strain on fibrous peat soils is calculated by the following equation:

$$
\varepsilon_{t}\left(t-t_{k}\right)=\Delta \sigma\left[a+b\left(1-e^{-\frac{\lambda}{b} t_{k}}\right)+b_{1}\left(1-e^{-\frac{\lambda 1}{b 1}\left(t-t_{k}\right)}\right)\right]
$$

where $\varepsilon t=$ Strain at time of $\mathrm{t}, t=$ Time of loading (minutes), $t_{k}=$ time of tertiary compression (minute), $\Delta \sigma^{\prime}=$ Addition of effective load ( $\left.\mathrm{kPa}\right), e=$ void ratio, $a=$ Primary compression parameters, $b=$ Secondary compression parameters, $b_{l}=$ tertiary compression parameters, $\lambda_{I} / b_{1}=$ Secondary compression velocity factor ( $1 /$ minute)

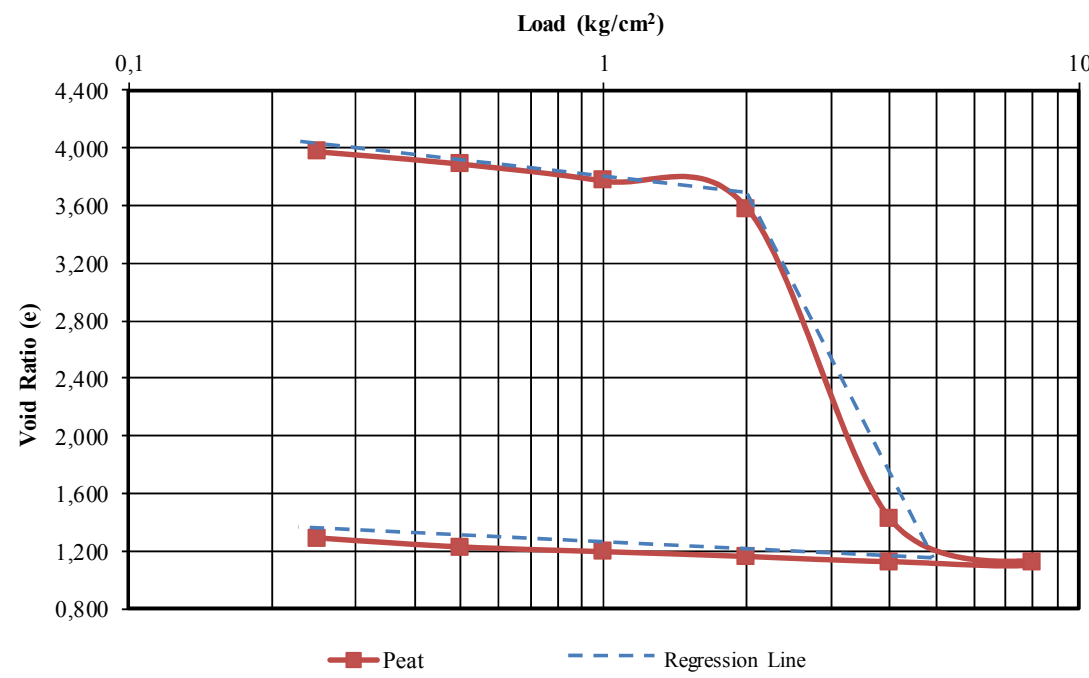

Fig. 4. Compression curve (e vs $\log \mathrm{t}$ ) by Terzaghi method of fibrous peat soil.

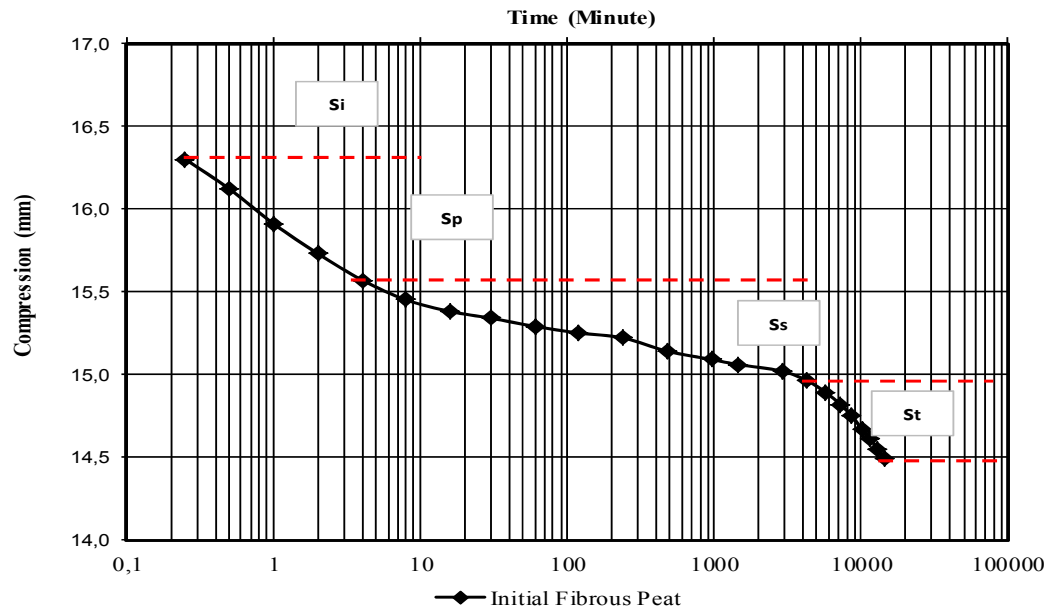

Fig. 5. Relationship curve $\Delta \mathrm{h}$ vs $\log \mathrm{t}$ on peat soil with $50 \mathrm{kPa}$ [9].

From the explanation of the physical and engineering properties of peat soil above, it is known that the characteristics of peat are very different from clay soil (inorganic soil), so 
the fibrous peat also has different treatment if the peat soil will be used as the foundation of a civil structure. Therefore, soil improvement methods used to improve bearing capacity of peat soil are generally classified into two types, namely mechanical methods and stabilization methods. However, the main priorities for selecting peat soil improvement methods are: peat soil thickness and its subsoil (Table 2), type of peat: fibrous or amorphous granular peat and the amount of compression to be overcome.

Table 2. Peat soil classification by thick layers of peat [21].

\begin{tabular}{|c|c|c|}
\hline Basic Classification & Category & Information \\
\hline \multirow{3}{*}{ Thick layers of peat } & $<1.0 \mathrm{~m}$ & Very shallow \\
\cline { 2 - 3 } & $1.0<2.0 \mathrm{~m}$ & Shallow \\
\cline { 2 - 3 } & $2.0-3.0 \mathrm{~m}$ & Deep \\
\cline { 2 - 3 } & $>3.0 \mathrm{~m}$ & Very deep \\
\hline
\end{tabular}

\section{Conclusions}

Based from the research it can be concluded that Palangkaraya peat soil classified as Hemic fibrous peat soil with low ash content and high acidity. The physical properties of Palangkaraya's peat soil are very different from clay due to the high organic content and specific pore structure. Peat fiber distribution is very influential on the value of shear angle. so the shear angle value is always different in every test. One step loading method is the right method to determine the compression of Palangkaraya peat soil due to pore structure which is very different from clay.

\section{References}

1. Van De Meene. Bull. Geological Research and Development Centre, 9 (1984)

2. I.C. MacFarlane, N.W. Radforth, Proceeding of The Tenth Muskeg Research Conference National Research Council of Canada (1965)

3. Canada National Research Council (CNRC), Peat Testing Manual Technical memorandum 125 (1979)

4. N.E. Mochtar, I. Ending, J. Teknik Sipil ITB, 6 (1999)

5. N.E. Mochtar, F.E. Yulianto, T.R. Satria, J. Teknik Sipil ITB, 21, 1 (2014)

6. N.E. Mochtar, F.E. Yulianto, Int. J. Adv. Sci. Eng. Information Tech. 8, 3 (2018)

7. R. Hasyim, S. Islam, J. of Appl. Sci. 8 (2008)

8. F. Harwadi, N.E. Mochtar, Proc. of the First Makassar International Conference on Civil Engineering (MICCE2010) (2010)

9. F.E. Yulianto, N.E. Mochtar, Proc. of 8th International Symposium on Lowland Technology (2012),

10. F.E. Yulianto, N.E. Mochtar, ARPN J. of Eng. and Appl. Sci. 11, 19 (2016)

11. P.K. Kolay, H. Sii, S.N.L. Taib, Int. J. of Civil and Env. Eng. 3, 2 (2011)

12. A.Ma'ruf, Pengaruh air di sekitar area lahan gambut yang distabilisasi terhadap sifat fisik dan sifat teknis tanah gambut (Tesis Program Magister FTSP-Institut Teknologi Sepuluh Nopember, Surabaya, 2012) 
13. H.C. Hardiyatmo, Mekanika tanah 1 (Gadjah Mada Univ. Press, Yogyakarta, 2002)

14. I.C. MacFarlane, Muskeg engineering handbook (Univ. of Toronto Press, Toronto, 1959)

15. L. Von Post, Sv. Mosskulturfor. Tidskr. 1 (1992)

16. J.I. Adam, Proc. Sixth International Conference on Soil Mechanics and Foundation Engineering (1965)

17. A.O. Landva, E.O. Korpijaakko, P.E. Pheeney, P.M. Jarret, Geotechnical classification of peats and organic soils ASTM, STP 820(1982)

18. K. Terzaghi, Eng. News Record 95 (1925)

19. R.W. Gibson, K.Y. Lo, Acta Polytecnica Scandinavia (1961)

20. A.W. Dhowian, T.B. Edil, Geotech. Testing J. 3, 3 (1980)

21. Wetlands International-Indonesia Programme, Peta sebaran lahan gambut, luas dan kandungan karbon di Kalimantan (Bogor, 2004) 